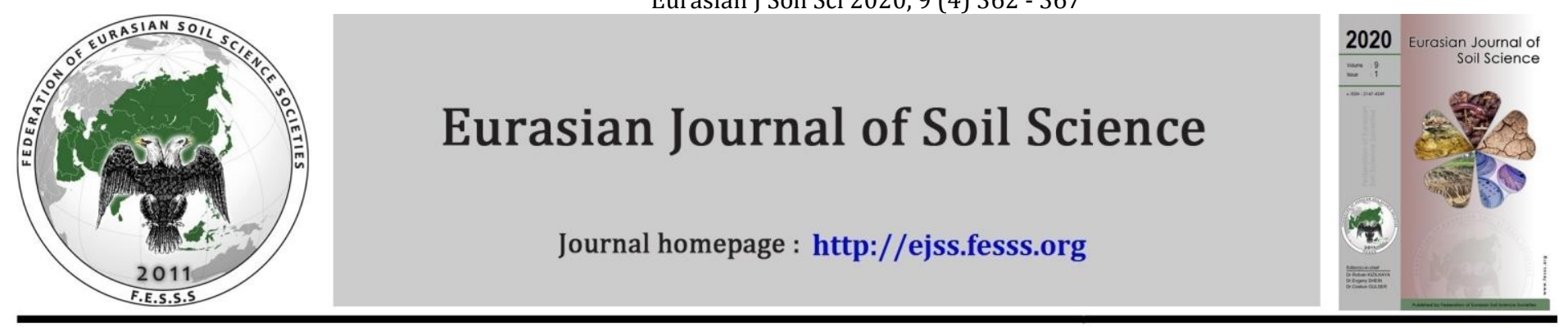

\title{
Effects of land and plant managements on soil erodibility in the Turhal District of Tokat, Turkey
}

\author{
Nutullah Özdemir *
}

Ondokuz Mayıs University, Faculty of Agriculture, Department of Soil Science and Plant Nutrition, Samsun, Turkey

\section{Article Info}

Received : 18.02 .2020

Accepted : 01.09.2020

\begin{abstract}
In this study, changes in the erodibility (sensitivity to erosion) values of soils under different land and plant managements (sunflower, wheat, vegetables, sugar beets, alfalfa fields as well as orchards, meadows and pastures) were examined in the Turhal district of Tokat province, Turkey. Physical and chemical properties of surface soil samples along with land management practices against erosion were investigated for their impact on sensitivity to erosion. The sensitivity of the soil samples were found to be in the following order: Meadows< orchards $<$ wheat $<$ sunflowers $<$ pastures $<$ sugar beets $<$ alfalfa $<$ vegetables. The findings show that fundamental soil characteristics, and especially clay and organic matter content, were effective in shaping the soil structure and therefore the erodibility, as well as the way the land was used. The most suitable parametric values in soil characteristics were observed in the meadows, and the worst values were observed in the soil where vegetables beets were planted. Keywords: Soil properties, plant management, erosion ratio.
\end{abstract}

(C) 2020 Federation of Eurasian Soil Science Societies. All rights reserved

\section{Introduction}

The preservation and improvement of multi-functional properties of lands are important for meeting the needs of the increasing population, developing economies and agricultural sustainability. Erosion adversely impacts the life cycle of soil by restricting its multi-functional properties (Tunç and Schröder, 2010). The effect of erosion on plant development is linked to reduced depths of roots, deterioration of soil structure, decrease in beneficial water reserves, loss of organic matter, and nutrition imbalance (Lal and Moldenhauer, 1987; Yllmaz et. al., 2007; Cebel et al., 2013). Fight against the negative effects of erosion in agricultural areas and the improvement of efficiency involve employing many options such as land management, soil management and plant management. The most general approach is to take necessary steps by identifying the level of impact or contribution of practices effective against soil erodibility by reducing the risk of potential erosion in these soils ahead and by increasing plant development, along with a suitable land management planning (Lal and Moldenhauer, 1987; Fleige and Horn, 2000; Başkan et al., 2011; Özdemir, 2013). The way a land is used and changes in vegetation significantly affect the organic matter, physical characteristics and erodibility (Francis and Thomes, 1990; Lal et al., 2018). Celik (2004) carried out a research study based on forests, pastures and agricultural areas. He found that the organic matter, bulk density, aggregate stability and erosion sensitivity of the soil had statistically significant changes due to the transformation of the forest and pasture areas into agricultural use. Eraslan et al. (2017) examined the relationship between the erosion sensitivities of the soil in the Inebolu Basin, the way the land was used and the vegetation cover on the land. They emphasized that there were statistically significant relationships between the sensitivity to erosion and clay content; and between vegetation cover and coverage. Parlak et al. (2015) examined the impact of pasture reclamation practices on soil erosion. They emphasized that there were significant differences in soil loss and bulk density values among protected and unprotected parcels.

It is known that plant root development in soils has an important positive effect on soil physical properties, especially structural development and stability (Iç et al, 2010; Iç and Gülser, 2012). Hacımüftüoğlu (2012)

* Nutullah Özdemir 函 : nutullah@omu.edu.tr D : 0000-0003-2554-3485 (Corresponding author) 
examined the physical, chemical and mechanical properties of these samples, and assessed the effects of the cultivated plants on the structural parameters of the soil sampledfrom the farmland of Faculty of Agriculture in Atatürk University where sunflowers, wheat, beans, corn, potatoes and alfalfa plants grown. They found that there were significant differences in the structural parameters and characteristics of the soil based on the types of the plants grown. The best parameter value in the soil samples was from the areas where alfalfa cultivated, and the worst value was from the soil where potatoes and corn cultivated.

This study was carried out to identify the effects of land and plant managements on physical and chemical soil characteristics and the sensitivity of soil against erosion, in the fields where sunflowers, wheat, vegetables, orchards, sugar beets, meadows, pastures and alfalfa plants were cultivated in the Turhal district of Tokat, Turkey.

\section{Material and Methods}

The research area is located within the boundaries of Turhal district of Tokat in the Central Black Sea region. Cereals are the main agricultural product in the district. In addition, tomatoes, sugar beets, sunflowers for oil production, feed crops (common vetch, alfalfa, corn for silage) and many types of fruit and vegetables are grown. A continental-temperate climate reigns in the region which is located in the transition zone between the Central Black Sea Region and the Central Anatolia Region. The average annual temperature is $12.9{ }^{\circ} \mathrm{C}$, and the average annual rainfall is $413.3 \mathrm{~mm}$ in the region (DMIGM, 2006).

This study was carried out with 24 surface $(0-20 \mathrm{~cm})$ soil samples taken from 3 different fields for 8 different land use (wheat, sunflowers, sugar beets, vegetables, alfalfa, orchards, meadows and pastures over three years) after harvesting.

\section{Methods}

Soil amples were analyzed using the standard methods as follows (Jones, 2001). Particle size distribution was determined by using the Bouyoucos hydrometer method. Soil pH (1:2.5) was detected using a pH-meter with glass electrode. Electrical conductivity was measured by using an electrical conductivity instrument with glass electrode. Organic matter content was identified by using the Walkley-Black method. Moisture contents at the field capacity $(0.33 \mathrm{~atm})$ and wilting point $(15.0 \mathrm{~atm})$ were detected by using a pressure plate. Lime content was measured by using a Scheibler Calcimeter, cation exchange capacity (CEC) by using the "Bower" method (Richards, 1954), and aggregate stability by using the wet sieving method (Demiralay, 1993). The dispersion rate was determined by using the silt + clay content values determined before and after the soil was dispersed in water (Özdemir, 2013). The soil erodibility factor was calculated by using the equation developed by Wischmeir and Smith (1978). The erosion rate was determined by using the moisture equivalent and clay content (Özdemir, 2013) with silt + clay content determined before and after the dispersion of the soil in water. Descriptive statistics for the obtained data and correlations among the soil properties were done using SPSS 11.0 software.

\section{Results Discussion}

Table 1 shows the statistical features determined in the soil samples taken from 24 land parcels hosting 8 different practices of land use (wheat, sunflowers, vegetables, orchards, sugar beets, meadows, pastures, and alfalfa cultivation) in the Turhal district of Tokat province. The soil samples had textures ranging from coarse to fine. The sand content of the soil samples ranged from $20.20 \%$ to $65.50 \%$, silt content from $19.30 \%$ to $45.10 \%$, and clay content from $1.40 \%$ to $41.20 \%$. pH values of the soil samples (1:2.5 earth-water) usually varied within the limits of moderately alkaline soil and was approximately 7.93 on average (Table 1). The soil samples had lime content ranging from moderately $(8.90 \%)$ to very $(39.50 \%)$ calcareous. Organic matter content in the soil samples had mostly a moderate level ranging from very little $(0.50 \%)$ to very high $(3.40 \%)$. The exchangeable sodium percentage in the soil samples was less than $15 \%$, and there was no problem of alkalinity (Hazelton and Murphy, 2007).

The erosion rate statistics identified in the soil samples taken from the (24) field s under (8) different land use conditions in the Turhal region is given in Table 1. Figure 1 shows the relationships between erosion rate averages and the way the lands were used. Table 2 shows the correlations between erosion rates and the soil characteristics. The erosion rates of the soil samples varied from $1.90 \%$ to $79.60 \%$, and the average value was $14.72 \%$ (Table 1). Erosion rate is a parameter that is employed to examine erosion sensitivity of soil, and any soil with a ratio smaller than $10 \%$ are considered resistant to erosion (Morgan, 2005). Among the soil parcels in the research site, the erosion rate in the samples higher than $10 \%$ limit value was found in 2 parcels of sunflower, 1 parcel of alfalfa, 3 parcels of vegetables, 2 parcels of sugar beets and 1 parcel of pasture. The soils in question can be said to be susceptible to erosion and the others are resistant to erosion. 


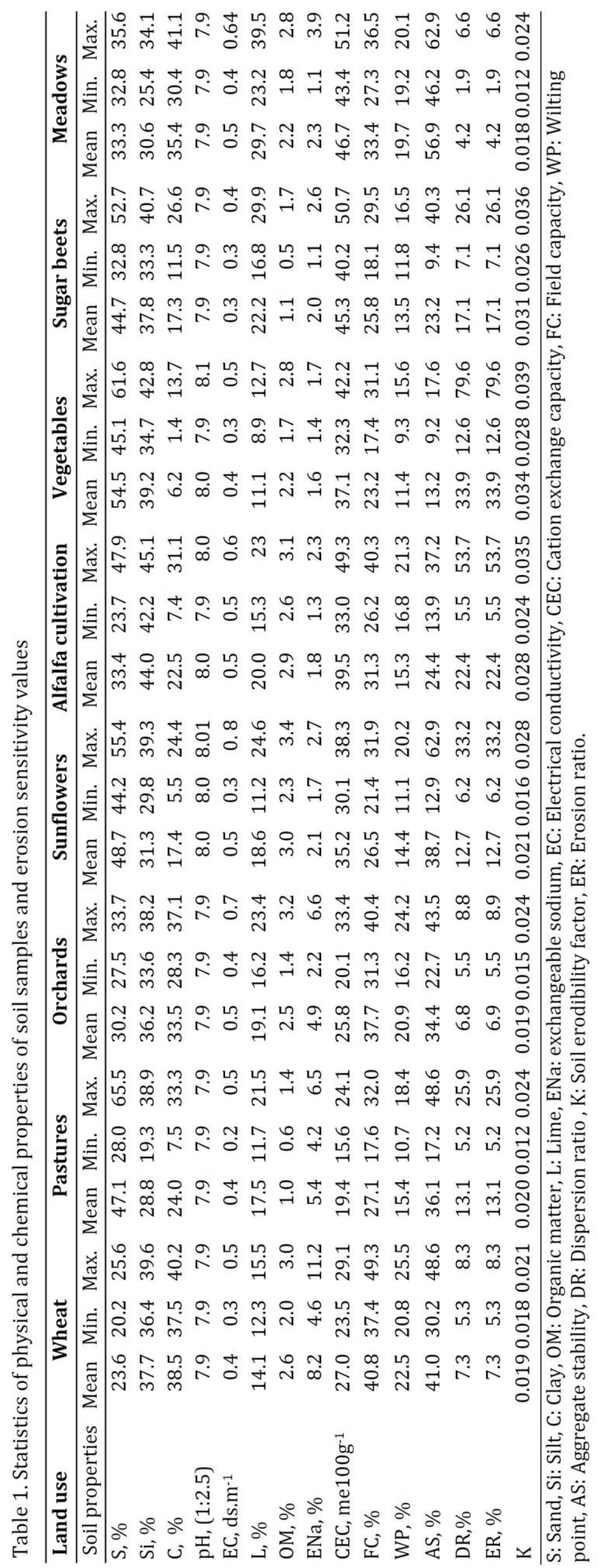


An analysis of the mutual relationships between the land use and erosion rate showed that sensitivity to erosion was influenced by basic soil characteristics and the ways the land was used. The tendency to erosion increased as the intensity of use increased, and parcels with a light texture and low organic matter were more sensitive to erosion (Table 1, Table 2). Kanar and Dengiz (2015) conducted a study in the Madendere Basin and examined the differences in the erosion sensitivity of the soil based on the way the land was used and the vegetation cover on the land. They stated that the sensitivity to erosion was affected by land use. Karagül (1994) found that an erosion-resistant structure was formed in the soils of meadows and forest areas, and an erosion-sensitive structure was formed in agricultural areas. The researcher stated that this situation was related to the structure that had been shaped for many years in the fields of meadows and pastures, and that the situation in agricultural areas was related to the insufficient development of a stable structure because of the continuous tillage of the land.

When the soil samples were sorted in ascending order in terms of erosion rates, the meadow-covered parcels $(1.90 \%)$ with the smallest proportion were found to be in the first place, while the parcels where vegetables were produced with the largest proportion $(79.60 \%)$ were last. It was found that the soil samples were in the following order: meadows $<$ orchards $<$ wheat $<$ sunflowers $<$ pastures $<$ sugar beets $<$ alfalfa $<$ vegetables. These findings show that basic soil characteristics, and especially clay and organic matter content, were effective in shaping the structure and therefore the sensitivity to erosion, as well as the way the land was used (Figure 1, Table 1). Özdemir (2015) and Benbi (1998) obtained similar findings in their research.

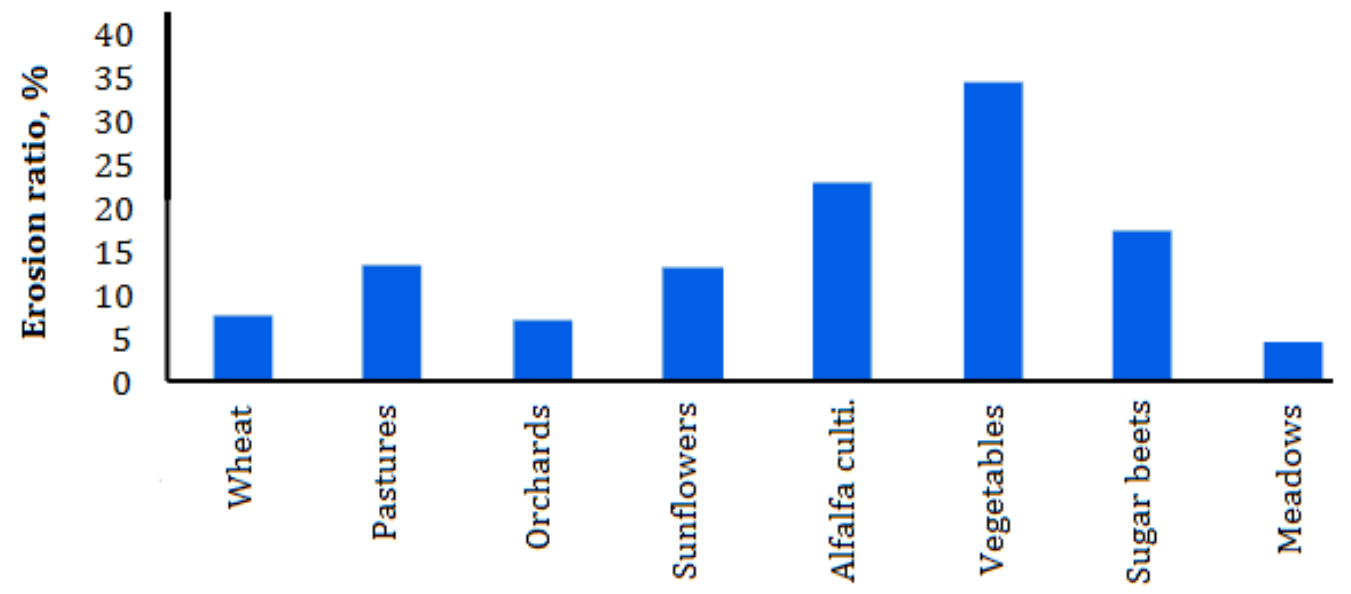

\section{Land use}

Figure 1. Change in erosion rates depending on the way the land was used

Erosion rate negatively correlated with the clay content $\left(-0.635^{* *}\right)$, organic matter $\left(-0.316^{*}\right)$, lime content $\left(-0.362^{*}\right)$, field capacity $\left(-0.590^{* *}\right)$, wilting point $\left(-0.667^{* *}\right)$ values of the soil samples, and positively correlated with the sand content $\left(0.518^{* *}\right)$ values of the soil samples significantly (Table 2). Gülser (2006) determined that aggregation is related to soil structure and different forage cropping treatments had positive effects on aggregation and aggregate stability by increasing soil organic carbon content, compared to the fallow control treatment of the clay soil.

Table 2. Correlation matrix for physical and chemical properties of soil samples

\begin{tabular}{|c|c|c|c|c|c|c|c|c|c|c|c|c|}
\hline & S & $\mathbf{S i}$ & C & OM & $\mathbf{L}$ & EC & CEC & FC & WP & AS & DR & ER \\
\hline $\mathbf{S i}$ & $-0,253$ & 1 & & & & & & & & & & \\
\hline C & $-0,892^{* *}$ & $-0,212$ & 1 & & & & & & & & & \\
\hline OM & $-0,607^{* *}$ & 0,036 & $0,597^{* *}$ & 1 & & & & & & & & \\
\hline $\mathbf{L}$ & $-0,185$ & $-0,379^{* *}$ & $0,364^{*}$ & 0,283 & 1 & & & & & & & \\
\hline EC & $-0,337^{*}$ & $0,361^{*}$ & 0,172 & $0,365^{*}$ & 0,010 & 1 & & & & & & \\
\hline CEC & $-0,055$ & 0,216 & $-0,045$ & 0,247 & $0,494^{* *}$ & 0,113 & 1 & & & & & \\
\hline FC & $-0,891^{* *}$ & 0,021 & $0,891^{* *}$ & $0,589^{* *}$ & 0,182 & $0,309^{*}$ & $-0,038$ & 1 & & & & \\
\hline WP & $-0,807^{* *}$ & $-0,138$ & $0,880^{* *}$ & $0,538^{* *}$ & 0,199 & $0,377^{* *}$ & $-0,158$ & $0,881^{* *}$ & 1 & & & \\
\hline AS & $-0,577^{* *}$ & $-0,426^{* *}$ & $0,782^{* *}$ & $0,593^{* *}$ & $0,456^{* *}$ & 0,128 & 0,072 & $0,586^{* *}$ & $0,664^{* *}$ & 1 & & \\
\hline DR & $0,676^{* *}$ & $-0,050$ & $-0,659^{* *}$ & $-0,588^{* *}$ & $-0,362^{*}$ & $-0,449^{* *}$ & $-0,241$ & $-0,685^{* *}$ & $-0,575^{* *}$ & $-0,598^{* *}$ & 1 & \\
\hline ER & $0,518^{* *}$ & 0,239 & $-0,635^{* *}$ & $-0,316^{*}$ & $-0,337^{*}$ & $-0,247$ & 0,049 & $-0,590^{* *}$ & $-0,667^{* *}$ & $-0,546^{* *}$ & $0,622^{* *}$ & 1 \\
\hline $\mathbf{K}$ & $0,478^{* *}$ & $0,662^{* *}$ & $-0,792^{* *}$ & $-0,487^{* *}$ & $-0,377^{* *}$ & $-0,062$ & 0,207 & $-0,631^{* *}$ & $-0,767^{* *}$ & $-0,741^{* *}$ & $0,440^{* *}$ & $0,653^{* *}$ \\
\hline
\end{tabular}

**: Significant at 1\% level, *: Significant at 5\% level, S: Sand, Si: Silt, C: Clay, OM: Organic matter, L: Lime, EC: Electrical conductivity, CEC: Cation exchange capacity, FC: Field capacity, WP: Wilting point, AS: Aggregate stability, DR: Dispersion ratio, K: Soil erodibility factor, ER: Erosion ratio. 
On the other hand, the erosion rates of the soil samples were found to have significantly positive correlations with the dispersion rate $\left(0.622^{* *}\right)$ and $\mathrm{K}$ factor $\left(0.653^{* *}\right)$ values, which are the parameters used in assessing structural stability, at $1 \%$ level, and significantly negative correlation with aggregate stability $\left(-0.546^{* *}\right)$ at $1 \%$ level (Table 2). Different researchers have obtained similar findings in their studies in different regions (García-Orenes et.al., 2009; Özdemir et al., 2015; Saygin et al., 2017). Gülser (2004) found that cropping treatments improved infiltration ratio by increasing sructural stability and porosity that can lead to the benefits of reduced erosion and improved soil water storage.

\section{Conclusion}

Sensitivity of soils to erosion in Turhal district was found to be affected by the land use, The lands used as meadow and pasture areas had soil structure more resistant to erosion than the lands used for vegetables production. Sensitivity to erosion was found to be affected by fundamental soil characteristics and especially clay and organic matter content. The parcels with high clay and organic matter content were determined to be more resistant to erosion. When the agricultural fields were considered, the sensitivity to erosion increased as the intensity of tillage increased and as the organic matter content of the soil decreased. It was observed that the fields involving the cultivation of feed crops created a structure that was more resistant than the parcels that required intensive tillage. In this respect, it will be useful to pay attention to these issues when deciding on alternation systems.

\section{References}

Başkan, O., Cebel, H., Keçeci, M., Depel, G., Bozkurt, M., 2011. Bölgesel mera alanlarındaki toprakların bazı fiziksel özellikleri ile aşınım arasındaki ilişkiler. II. Ulusal Toprak Su Kaynakları Kongresi, Ankara, pp. 539-549. [in Turkish].

Benbi, D.K., Biswas, C.R., Bawa, S.S., Kumar, K., 1998. Influence of farmyard manure, inorganic fertilizers and weed control practices on some soil physical properties in a long-term experiment. Soil Use and Management 14(1): 52-54.

Cebel, H., Akgül, S., Doğan, O., Elbaşı, F., 2013. Erodibility "K" factor of great soil groups in Turkey. Soil Water Journal 2(1): 30-45. [in Turkish].

Celik, İ., 2004. Land-use effects on organic matter and physical properties of soil in a Southern Mediterranean highland of Turkey. Soil and Tillage Research 83(2): 270-277.

Demiralay, İ., 1993. Methods of soil physical analyses. Atatürk Faculty of Agriculture, Erzurum, Turkey. [in Turkish].

DMİGM, 2006. Turhal Meteoroloji İstasyonu Yayımlanmamış Döküm Cetvelleri. Turhal.

Eraslan, S., İmamoğlu, A., Coşkun, A., Saygın, F., Dengiz, O., 2017. Determination of relationship between situation of soil erosion sensitivity and land use/land cover in Inebolu Basin Soils. Yuzuncu Yll University Journal of Agricultural Sciences 27(1): 95-108. [in Turkish].

Fleige, H., Horn, R., 2000. Surface runoff, erosion and loss of nutrients in traffic ruts of agricultural soils (Luvisols) in a hilly moraine landscape in Germany. In: Proceedings of the 15th ISTRO Conference, Tillage at the Threshold of the 21st Century, Lowery, B., Morrison, J., Kirby, M. (Eds.). June 2-7, 2000, Fort Worth, Texas, U.S.A.

Francis, C.F., Thornes, J.B., 1990. Runoff hydrographs from three Mediterranean vegetation cover types. In: Vegetation and Erosion: Processes and Environments. Thornes, J.B. (Ed.). John Wiley \& Sons Ltd., Chichester, pp. 363-384.

García-Orenes, F., Cerdà, A., Mataix-Solera, J., Guerrero, C., Bodí, M.B., Arcenegui, V., Sempere, J.G., 2009. Effects of agricultural management on surface soil properties and soil-water losses in eastern Spain. Soil and Tillage Research 106(1): 117-123.

Grossman, R.B., Brasher, B.R., Franzmeier, D.P., Walker, J.L., 1968. Linear extensibility as calculated from natural clod bulk density measurements. Soil Science Society of America Journal 32(4): 570-573.

Gülser, C., 2004. A comparison of some physical and chemical soil quality indicators influenced by different crop species. Pakistan Journal of Biological Sciences 7(6): 905-911.

Gülser, C., 2006. Effect of forage cropping treatments on soil structure and relationships with fractal dimensions. Geoderma 131(1-2): 33-44.

Hacımüftüoğlu, F., 2012. Changes in structural parameters of soils formed on similar conditions but under different cropping systems. MSc Thesis, Atatürk Üniversity, Erzurum, Turkey. [in Turkish].

Hazelton, P., Murphy, B., 2007. Interpreting soil test results: what to do all the numbers mean? CSIRO Publishing. Collingwood Victoria, Australia. 152p.

İç S., Gülser C., Candemir F., Demir Z., 2010. Effects of plant growth on some physical properties of different textured soils. In: Proceedings of the International Soil Science Congress on Management of Natural Resources to Sustain Soil Health and Quality. Kizilkaya, R., Gülser, C., Dengiz, O., (Eds.), May 26-28, 2010. Samsun, Turkey. pp. 10721077.

İç, S., Gülser, C., 2012. Effects of rice husk application and planting on some properties of different textured soils. In: Proceedings of the $8^{\text {th }}$ International Soil Science Congress on "Land Degradation and Challenges in Sustainable Soil Management" May 15-17, 2012. Çeşme-İzmir, Turkey, Vol:2, p. 98-102.

Jones, J.B., 2001. Laboratory guide for conducting soil tests and plant analyses. CRC Press, New York, USA. 363p. 
Kanar, E., Dengiz, O., 2015. Determination of relatinship between land use/land cover and some erodibility undexes in Madendere watershed soils. Turkish Journal of Agricultural Research 2: 15.27 [in Turkish].

Karagül, R., 1994. Investigations on soil erodibility and some properties of the soils under different land use types in Söğütlüdere Creek watershed near Trabzon. PhD Thesis. Karadeniz Technical University, Trabzon, Turkey. [in Turkish].

Lal, R., Mokma, D., Lowery, B., 2018. Relation between soil quality and erosion. In: Soil quality and soil erosion. Lal, R. (Ed.). CRC Press, Washington DC, USA. pp. 237-258.

Lal, R., Moldenhauer, W.C., 1987. Effects of soil erosion on crop productivity. Critical Reviews in Plant Sciences 5(4): 303367.

Morgan, R.P.C., 2005. Soil Erosion and Conservation. Blackwell Publishing Ltd. UK. 198p.

Özdemir, N., 2013. Soil and Water Conservation. Ondokuz Mayıs University, Faculty of Agriculture, No 22, Samsun, Turkey. [in Turkish].

Özdemir, N., Öztürk, E., Durmus, Ö. T. K., Ekberli, İ., 2015. Effects of organic and inorganic amendments on soil erodibility. Eurasian Journal of Soil Science, 4(4): 266-271.

Parlak, M., Alatürk, F., Özaslan, Parlak, A., Gökkuș, A., 2015. Effect of different improvement applications to soil erosion in shrubby rangelands of Gökçeada (Canakkale). COMU Journal of Agriculture Faculty 3(1): 123-132. [in Turkish].

Richards, L.A., 1954. Diagnosis and improvement of saline and alkali soil. US Salinity Lab. Staff, U.S. Department of Agriculture, Agricultural Research Service, Handbook 60. Washington D.C., USA. 160p.

Saygın, F., Dengiz, O., İç, S., 2019. Relationships between erodibility and some soil properties of soils in micro chatchment scale. Water Soil Journal Special Issue, 15-23 [in Turkish].

Tunç, E. Schröder, D., 2010. Determination of the soil erosion level in agricultural lands in the western part of Ankara by USLE. Ekoloji 75: 58-63. [in Turkish].

Wischmeier, W.H., Smith, D.D., 1978. Predicting rainfall erosion loses a guide to conservation planning. United States Department of Agronomy, Agriculture Handbook No:557, Washington, USA. 163p.

Yilmaz, M., Usta, A., Altun, L., Tilki, F., 2007. Effects of land-use regime on soil erodibility indices and soil properties in Unye, Turkey. Fresenius Environmental Bulletin 16(12B): 1638-1644. 